\title{
PENELUSURAN BANJIR BERDASARKAN ANALISIS METODE KINEMATIK BERBASIS SISTEM INFORMASI GEOGRAFIS (SIG) DI KELURAHAN SANGKRAH, SURAKARTA
}

\author{
Nabilla Khairunnisa Ishadi'), Rintis Hadiani' ${ }^{2}$, dan Endah Sitaresmi Suryandari ${ }^{3}$ \\ 1) Mahasiswa Fakultas Teknik, Prodi Teknik Sipil, Universitas Sebelas Maret \\ 2) Pengajar Fakultas Teknik, Prodi Teknik Sipil, Universitas Sebelas Maret \\ 3) Kepala Dinas Pekerjaan Umum Kota Surakarta \\ Jl. Ir. Sutami 36A, Surakarta 57126; Telp. 0271-634524. Email: $\underline{\text { sshadinabilla@gmail.com }}$
}

\begin{abstract}
Sangkerah is one of the areas in Surakarta that usually flooded due to water runoff from Kali Pepe Hilir that flows in the north of its areas. One of the flood prevention action is to create inundation mapping based on flood routing using the Kinematic method. Flood routing is used to determine the flood discharge that occurs, which will then be mapped using Geographic Information System (GIS). The mapping process is based on events of 5, 10, 25, 50, 100 years return period and 3-days rainfall.

The result of this research shows that maximum debit for 5 years return period is $37,295 \mathrm{~m}^{3} /$ second, potentially obtaining a maximum water level of 1,702 $\mathrm{m}$ that caused inundation area 10.113,433 $\mathrm{m}^{2}$. The maximum debit for 10 years return period is 41,485 $\mathrm{m}^{3} /$ second, potentially obtaining a maximum water level of 1,876 $\mathrm{m}$ that caused inundation area 10.083,676 $\mathrm{m}^{2}$. The maximum debit for 25 years return period is $44,475 \mathrm{~m}^{3} /$ second, potentially obtaining a maximum water level of 1,972 $\mathrm{m}$ that caused inundation area 10.314,6 $\mathrm{m}^{2}$. The maximum debit for 50 years return period is 49,224 $\mathrm{m}^{3} /$ second, potentially obtaining a maximum water level of 2,117 $\mathrm{m}$ that caused inundation area 10.352,767 $\mathrm{m}^{2}$. The maximum debit for 100 years return period is 52,204 $\mathrm{m}^{3} /$ second, potentially obtaining a maximum water level of 2,207 $\mathrm{m}$ that caused inundation area 10.473,183 $\mathrm{m}^{2}$. The maximum 3-days rainfall debit happened in the year of 2007 is 101,73 $\mathrm{m}^{3} /$ second, potentially obtaining a maximum water level of 3,601 $\mathrm{m}$ that cause inundation area $12.880 .043 \mathrm{~m}^{2}$.
\end{abstract}

Keywords : Sangkrah Village, Flood Routing, Kinematic Method, Geographical Information System.

\begin{abstract}
Abstrak
Kelurahan Sangkrah merupakan salah satu wilayah di Kota Surakarta yang biasa tergenang banjir akibat limpasan air dari Kali Pepe Hilir yang mengalir di sebelah utara dari daerah kelurahan. Salah satu tindakan penanganan banjir adalah dengan membuat pemetaan wilayah tergenang berdasarkan penelusuran banjir dengan metode Kinematik. Penelusuran banjir (flood routing) dilakukan untuk mengetahui debit banjir yang terjadi, yang kemudian akan dipetakan dengan menggunakan Sistem Informasi Geografis (SIG). Pemetaan banjir dilakukan berdasarkan Q $5, \mathrm{Q}_{10}, \mathrm{Q}_{25}, \mathrm{Q}_{50}, \mathrm{Q}_{100}$, dan $\mathrm{Q}_{3 \text {-harian. }}$

Hasil dari penelitian ini menunjukkan bahwa debit banjir rencana periode ulang 5 Tahun (Q5) adalah 37,295 $\mathrm{m}^{3} /$ detik, berpotensi menghasilkan tinggi muka air maksimum 1,702 $\mathrm{m}$ dan luasan tergenang $9.290,346 \mathrm{~m}^{2}$. Debit periode ulang 10 Tahun $\left(\mathrm{Q}_{10}\right)$ adalah $41,4855 \mathrm{~m}^{3}$ /detik berpotensi menghasilkan tinggi muka air maksimum 1,876 $\mathrm{m}$ dan luasan tergenang 10.083,676 $\mathrm{m}^{2}$. Debit periode ulang 25 Tahun $\left(\mathrm{Q}_{25}\right)$ adalah 44,475 $\mathrm{m}^{3} /$ detik, berpotensi menghasilkan tinggi muka air maksimum 1,970 $\mathrm{m}$ dan luasan tergenang 10.314,6 $\mathrm{m}^{2}$. Debit periode ulang 50 Tahun $\left(\mathrm{Q}_{50}\right)$ adalah, 49,224 $\mathrm{m}^{3} / \mathrm{detik}$, berpotensi menghasilkan tinggi muka air maksimum 2,117 $\mathrm{m}$ dan luasan tergenang $10.352,767 \mathrm{~m}^{2}$. Debit periode ulang 100 Tahun $\left(\mathrm{Q}_{100}\right)$ adalah 52,204 m³ /detik, berpotensi menghasilkan tinggi muka air maksimum 2,207 $\mathrm{m}$ dan luasan tergenang $10.473,183 \mathrm{~m}^{2}$. Debit banjir rencana maksimum akibat hujan 3-harian maksimum tahunan terjadi pada tahun 2007 yakni sebesar 101,73 m³/detik, berpotensi menghasilkan tinggi muka air maksimum 3,601 m dan luasan tergenang $12.880,043 \mathrm{~m}^{2}$.
\end{abstract}

Kata kunci: Kelurahan Sangkrah, Penelusuran Banjir, Metode Kinematik, Sistem Informasi Geografis.

\section{PENDAHULUAN}

Banjir adalah suatu kondisi dimana tidak tertampungnya air dalam saluran pembuang atau terhambatnya aliran air di dalam saluran pembuang (Suripin, 2004). Kelebihan air dapat disebabkan oleh berbagai hal, salah satunya adalah kenaikan intensitas curah hujan yang tinggi, yakni peningkatan intensitas curah hujan secara dinamis dan signifikan (Kodoatie, 2006).

Kota Surakarta atau lebih dikenal dengan Kota Solo secara umum merupakan dataran rendah dengan ketinggian rata-rata +92 m DPL, dan secara geografis terletak di lembah dan tempuran sungai menyebabkan mudah sekali terjadi banjir. Salah satu sungai yang membelah Kota Solo adalah Kali Pepe. Pada perkembangannya, pemerintah melalui Balai Besar Wilayah Sungai Bengawan Solo, membagi Sungai Pepe ini ke dalam dua bagian untuk mempermudah pengelolaan badan sungai. Kali Pepe Hulu mengalir dari mulai Kabupaten Boyolali hingga berakhir di Bendung Karet Tirtonadi. Kemudian, bagian sungai yang mengalir ke selatan kota Surakarta hingga berakhir di Pintu Air Demangan ini dinamakan Kali Pepe Hilir.

Banjir dapat diteliti dengan memperhatikan sejarahnya, sehingga bisa diketahui trend atau kecenderunganya. Pada penelitian banjir yang dimaksud adalah banjir periode ulang 2, 510 , 20, hingga 50 tahunan $\left(\mathrm{Q}_{2}, \mathrm{Q}_{5}, \mathrm{Q}_{10}, \mathrm{Q}_{20}\right.$, dan 
Q50). Untuk mengetahui elevasi dan tinggi muka air banjir, dilakukan penelusuran banjir dengan menggunakan metode Kinematik. Menurut BNPB (2016), suatu kondisi disebut sebagai bencana banjir jika banjir disebabkan oleh hujan 3 (tiga) harian berturut-turut atau disebut sebagai hujan 3 (tiga) harian. Pada penelitian ini dipilih hujan 3 (tiga) harian maksimum tahunan. Hujan ini akan menyebabkan hujan yang bisa dianggap sebagai bencana.

Pemetaan bencana banjir berdasarkan sejarah banjir (flood history) tentu akan memberikan peranan dalam membantu untuk memprediksi kemungkinan terjadinya bencana banjir di waktu yang akan datang. Seiring degan perkembangan teknologi, kini Sistem Informasi Geografis juga dapat mengolah data non-spasial. Pemanfaatan perangkat lunak ArcMap dalam pemetaan wilayah banjir sekaligus pengolahan data, biasanya digunakan Teknik Geoprocessing.

Untuk menghasilkan peta, diperlukan beberapa perhitungan yang meliputi perhitungan besar debit banjir tahunan yang kemungkinan terjadi di lokasi penelitian dengan memanfaatkan data hujan dari tiga stasiun hujan terdekat dalam kurun waktu 20 tahun terakhir. Analisis yang dilakukan berdasarkan data hujan harian dan hujan tiga harian, untuk kemudian menjadi dasar perhitungan perkiraan debit kala ulang 2, 5, 10, dan 2 tahun. Kemudian, dilakukan penelusuran banjir (flood routing) untuk mengetahui seberapa besar elevasi muka air yang terjadi ketika banjir. Hasil perhitungan elevasi banjir ini kemudian dikombinasikan dengan properti sungai menjadi input dalam pemetaan bencana banjir di Kecamatan Sangkrah, Kelurahan Pasar Kliwon, Kota Surakarta.

\section{LANDASAN TEORI}

Penelusuran banjir adalah suatu metode yang dilakukan unutk menentukan waktu dan debit aliran (hidrogaf) di suatu titik aliran berdasarkan hidrograf di suatu titik aliran berdasarkan hidrograf sebelah hulu (Bambang Triatmodjo, 2009). Menurut Soemarto (1993), penelusuran banjir merupakan perkiraan hidrograf di suatu titik pada suatu aliran atau bagian sungai yang didasarkan atas pengamatan hidrograf di titik lain. Tujuan penelusuran banjir banjir adalah untuk perkiraan banjir jangka pendek, perhitungan hidrgraf satuan untuk berbagai titik sepanjang sungai dari hidrograf satuan di suatu titik di sungai tersebut.

Dalam pemetaan potensi banjir, terdapat beberapa perangkat lunak yang umum digunakan, salah satunya adalah ArcMap dengan basis Sistem Informasi Geografis (SIG). Cahyono dkk. (2015) menggunakan ArcMap untuk pemodelan spasial banjir dengan ekstensi HEC-GeoRAS. Monica Pratt (2004) menjelaskan bahwa perangkat ArcMap dapat bekerja dengan baik dengan Microsoft Excel. Data nonspasial yang dibuat serta diolah di Microsoft Excel dapat secara langsung dikoneksikan serta ditampilkan dalam perangkat floo.

\section{Pengisian Data Hujan yang Hilang}

Simanton et al (1980) menggunakan reciprocal method (inversed squared distance) dalam pengisian data hujan yang hilang, dengan memanfaatkan jarak antar stasiun sebagai faktor koreksi (weighting factor). Data hujan harian yang hilang dapat dihitung dengan menggunakan Persamaan 1.

$$
\boldsymbol{P} \boldsymbol{x}=\frac{\sum_{i=1}^{n} \frac{P_{i}}{L_{i}^{2}}}{\sum_{i=1}^{n} \frac{1}{L_{i}^{2}}}
$$

dengan:

$P x=$ data curah hujan pada stasiun $\mathrm{X}$ yang diperkirakan data hilang

$P_{i} \quad=$ data hujan di sekitarnya pada periode yang sama

$L_{i} \quad=$ jarak antar stasiun

\section{Kepanggahan Data}

Uji konsistensi atau kepanggahan dilakukan untuk mengetahui apakah data layak digunakan atau tidak. Uji konsistensi yang digunakan dalam penelitian ini adalah metode kurva massa ganda (double mass curve). Metode ini dipilih karena data hujan akan digunakan untuk desain periode ulang. Konsistensi data hujan dengan metode kurva massa ganda bisa juga dilihat dengan nilai koefisien deterministik $\left(r^{2}\right)$. Model regresi dikatakan sempurna apabila $r^{2}=1$. Adapun koefisien deterministik antara variabel $x$ dan $y$ dapat dicari dengan Persamaan 2.

$$
\begin{aligned}
& \boldsymbol{r}^{2}=\frac{\sum \boldsymbol{x}_{i} y_{i}-\sum \boldsymbol{x}_{i} \sum y_{i} / n^{2}}{\sum \boldsymbol{x}_{i}^{2}-\left(\sum \boldsymbol{x}_{i}\right)^{2} / n\left(\sum y_{i}\right)^{2}-\left(\sum y_{i}\right)^{2} / n} \\
& \text { dengan: } \\
& i \quad=\text { data ke } \\
& n \quad=\text { jumlah data }
\end{aligned}
$$




\section{Hujan Wilayah}

Hujan wilayah atau hujan daerah adalah hujan titik dari beberapa stasiun hujan yang diolah dan dianggap mewakili hujan yang terjadi di suatu DAS. Penelitian ini menggunakan metode polygon Thiessen, karena memperhitungkan bobot masing-masing stasiun yang mewakili kawasan di sekitarnya. Metode Thiessen mengasumsi bahwa pada suatu titik manapun di dalam daerah tangkapan. Metode ini juga menerapkan perhitungan berdasarkan rata-rata timbang (weighted avereage), dengan memberikan proporsi luasan daerah pengaruh stasiun hujan untuk mengakomodasi ketidakseragaman jarak. Perhitungan hujan wilayah dengan metode Poligon Thiessen dapat menggunakan Persamaan 3 berikut.

$\bar{p}=\frac{A_{1} p_{1}+A_{2} p_{2}+\cdots+A_{n} p_{n}}{A_{1}+A_{2}+\cdots+A_{n}}$

dengan:

$\mathrm{p} \quad=$ hujan rerata kawasan

$\mathrm{p}_{1}, \mathrm{p}_{2}, \ldots \mathrm{p}_{\mathrm{n}} \quad=$ hujan di stasiun $1,2,3, \ldots . \mathrm{n}$

$\mathrm{A}_{1}, \mathrm{~A}_{2}, \ldots \mathrm{A}_{\mathrm{n}} \quad=$ luas daerah yang mewakili stasiun $1,2, \ldots \mathrm{n}$

\section{Distribusi Sebaran}

Perhitungan dengan menggunakan distribusi Log Pearson III banyak digunakan dalam analisis data maksimum banjir dan debit minimum dengan nilai ekstrem. Bentuk distribusi log Pearson tipe III merupakan hasil transformasi dari distribusi Pearson tipe III dengan menggantikan variat menjadi nilai logaritmik. Persamaan garis lurus bentuk kumulatif distribusi Log Pearson tipe III adalah (Soewarno, 1995) dapat dilihat pada

\section{Persamaan 4.}

$\boldsymbol{Y}=\overline{\boldsymbol{Y}}-\boldsymbol{k} \cdot \boldsymbol{S}$

dengan:

$\mathrm{Y} \quad=$ nilai logaritmik dari $\mathrm{X}$

$\bar{Y} \quad=$ nilai rata-rata dari $\mathrm{Y}$

$\mathrm{S} \quad=$ deviasi standar dari $\mathrm{Y}$

$\mathrm{K} \quad=$ karakteristik dari distribusi Log Pearson Tipe III

\section{Kecocokan Sebaran}

Analisis pada penelitian ini menggunakan uji kecocokan Smimov-Kolmogorov. Pengujian dilakukan dengan cara membandingkan probabilitas pada tiap-tiap variabel dari suatu distribusi yang hasilnya akan didapat perbedaan $(\Delta)$. Perbedaan maksimum $\left(\Delta_{\text {maks }}\right)$ yang dihitung dibandingkan dengan perbedaan kritis $\left(\Delta_{\text {cr }}\right)$ untuk banyaknya varian tertentu. Sebaran dikatakan sesuai jika $\Delta_{\text {maks }}<\Delta_{\text {cr }}$ (Soewarno, 1995).

\section{Curve Number}

Curve Number adalah fungsi dari karakteristik DAS seperti tipe tanah, tanaman penutup, tata guna lahan, kelembaban, dan cara pengerjaan tanah. Nilai CN bervariasi dari 0 hingga 100.

\section{Hujan Efektif}

The Soil Conservation Service (SCS, 1972, dalam Chow, 1988) telah mengembangkan metode untuk menghitung hujan efektif dalam Persamaan 5 berikut ini (Bambang Triatmodjo, 2008).

$\boldsymbol{P}_{e}=\frac{(P-0,2 S)^{2}}{P+0,8 S}$

dengan:

$P_{e} \quad=$ kedalaman hujan efektif $(\mathrm{mm})$

$P \quad=$ kedalaman hujan $(\mathrm{mm})$

$S=$ retensi potensial maksimum air oleh tanah, yang sebagian besar karena infiltrasi ( $\mathrm{mm})$

Persamaan 5 adalah persamaan dasar untuk menghitung kedalaman hujan efektif. Retensi potensial maksimum dapat dihitung dengan Persamaan 6 berikut ini (SCS, 1972).

$S=\frac{25400-254 C N}{C N}$

dengan:

$S=$ retensi potensial maksimum air oleh tanah, yang sebagian besar karena infiltrasi (mm)

$C N=$ Curve Number 


\section{Waktu Konsentrasi}

Waktu konsentrasi adalah waktu yang diperlukan untuk bergeraknya air dari titik aliran terjauh dari suatu DAS sampai dengan titik pelepasan. Pada penelitian ini, digunakan rumus Kirpich seperti ditampilkan pada Persamaan 7 (Tata Cara Perhitungan Debit Banjir Rencana, SNI 2415:2016).

$t_{c}=\mathrm{f} \cdot L^{0,77} \cdot S^{-0,385}$

dengan:

$$
\begin{array}{ll}
t_{c} & =\text { waktu konsentrasi }(\mathrm{jam}) \\
\mathrm{L} & =\text { panjang saluran utama lintasan air }(\mathrm{km}) \\
\mathrm{S} & =\text { kemiringan rata-rata saluran }(\Delta \mathrm{H} / \mathrm{L}) \\
\mathrm{f} & =\text { konstanta konversi satuan, diisi } 0,01947
\end{array}
$$

\section{Intensitas Hujan}

Intensitas curah hujan adalah ketinggian curah hujan yang terjadi pada suatu kurun waktu di mana air tersebut berkonsentrasi. Penelitian ini menggunakan metode Mononobe hasil modifikasi dengan rumus yang disajikan pada Persamaan 8 (Rosadana Nurir, 2015).

$I_{t}=\frac{R_{24}}{\boldsymbol{t}_{\boldsymbol{c}}}\left[\frac{\boldsymbol{t}_{c}}{\boldsymbol{t}}\right]^{2 / 3}$

dengan:

$$
\begin{array}{ll}
I_{t} & =\text { Intensitas curah hujan pada jam ke- } t(\mathrm{~mm} / \mathrm{jam}) \\
R_{24} & =\text { tinggi hujan rancangan dalam } 24 \mathrm{jam}(\mathrm{mm}) \\
t_{c} & =\text { waktu konsentrasi (jam) } \\
t & =\text { jam ke-1 s.d. jam ke- } t c
\end{array}
$$

\section{Hidrograf Satuan Sintetis Soil Conservation Service (HSS SCS)}

HSS Soil Consevation Service (SCS) adalah hidrograf satuan sintetis yang dikembangkan oleh Victor Mockus pada tahun 1950 dengan lokasi penelitian di Amerika Serikat. Hidrograf ini menggunakan fungsi hidrograf tanpa dimensi untuk menyediakan bentuk standar hidrograf satuan. Persamaan yang digunakan dalam perhitungan HSS SCS mengikuti Persamaan 9 sampai dengan Persamaan 17 (BSNI, 2016).

$$
\begin{aligned}
& Q p=q p \cdot P e \cdot 0,028 \\
& q p=\frac{A}{T_{0} \text { terkoreksi }} \cdot 484 \\
& \text { To tker }=\frac{\text { Time ratio. } T_{c}}{1,5} \\
& \frac{T_{0}}{T_{p}}=\frac{T_{r} \cdot T_{c}}{T_{p}} \\
& T_{c}=0,01947 \cdot L^{0,77} \cdot S^{-0,385} \\
& T p=\frac{0,24 \cdot t_{c}}{2}+t_{p} \\
& \text { tp }=0.51 \cdot \mathrm{L} 0,8 \\
& P e=\frac{(P-0,2 S)^{2}}{P+0,8 \mathrm{~S}} \\
& S=\frac{25400}{C N}-254 \\
& \text { dengan: } \\
& Q_{p}=\text { debit puncak limpasan }\left(\mathrm{m}^{3} / \mathrm{s}\right) \\
& q_{p}=\text { debit puncak (in) } \\
& T_{c}=\text { waktu konsentrasi (jam) } \\
& T_{p}=\text { waktu puncak }\left(\mathrm{m}^{3} / \mathrm{s}\right) \\
& t_{p}=\text { waktu antara titik berat curah hujan hingga puncak hidrograf (jam) } \\
& t_{r}=\text { time ratio } \\
& A=\text { luas DAS (in) } \\
& L \quad=\text { panjang sungai utama }(\mathrm{km}) \\
& S=\text { kemiringan sungai } \\
& P_{e}=\text { kedalaman hujan efektif (in) } \\
& P=\text { kedalaman hujan maksimum (in) } \\
& S=\text { infiltrasi maksimum yang terjadi (in) }
\end{aligned}
$$




\section{Penelusuran Banjir}

Chow dkk. (1998) menerangkan bahwa penelusuran banjir kinematik didapatkan dari penyederhanaan persamaan Saint Vennant dan hukum kekekalan momentum, dimana kemiringan dasar saluran sama dengan kemiringan muka air (Hendrayani, 2007). Penelusuran banjir metode kinematik dilakukan dengan persamaan linear. Penelusuran akan berjalan bertahap pada kotak-kotak hubungan waktu (j) dan jarak (i). Jika debit pada (i,j+1) dan $(i+1, j)$ sudah diketahui, maka debit pada jarak $(i+1)$ dan waktu $(j+1)$ juga akan diketahui.

Seperti yang sudah disebutkan sebelumnya, penelusuran banjir dengan metode kinematik menerapkan persamaan rumus Saint Vennant, yang ditunjukkan pada Persamaan 18 dan 19 berikut.

$\alpha=\left(\frac{n p^{2 / 3}}{\sqrt{S}}\right)^{0,6}$

$Q_{i+1}^{j+1}=\frac{\left[\frac{\Delta t}{\Delta x} Q_{i}^{j+1}+\alpha \beta\left(\frac{Q_{i+1}^{j}+Q_{1}^{j+1}}{2}\right)^{\beta-1}\right]}{\left[\frac{\Delta t}{\Delta x}+\alpha \beta\left(\frac{Q_{i+1}^{j}+Q^{j+1}}{2}\right)^{\beta-1}\right]}$

dengan:

$\mathrm{Q}=$ debit alliran $\left(\mathrm{m}^{3} /\right.$ detik)

$\beta=$ koefisien momentum

$\Delta \mathrm{t} \quad=$ interval waktu (detik)

$\Delta \mathrm{x} \quad=$ interval jarak (meter)

$\mathrm{n}=$ koefisien kekasaran Manning

$\alpha \quad=$ kecepatan aliran ( $\mathrm{m} /$ detik)

$\mathrm{P} \quad=$ lebar permukaan atas sungai (meter)

$S=$ kemiringan $($ slope $)$ dasar aliran

$\mathrm{i} \quad=$ step waktu

j $\quad=$ step jarak

\section{Persamaan Debit}

Proses penelusuran banjir kemudian menghasilkan debit, yang akan digunakan dalam menentukan tinggi permukaan air yang terjadi di titik tinjauan tersebut. Penelitian ini menggunakan persamaan debit Manning yang dapat dilihat pada Persamaan 20 berikut ini.

$Q=A\left(\frac{1}{n} R^{2 / 3} S^{1 / 2}\right)$

dengan:

$\mathrm{Q}=\operatorname{debit}\left(\mathrm{m}^{3} /\right.$ detik $)$

A $=$ luas penampang melintang $\left(\mathrm{m}^{2}\right)$

$\mathrm{n} \quad=$ koefisien Manning

$\mathrm{R} \quad=$ panjang jari-jari hidrolik

$\mathrm{S} \quad=$ kemiringan dasar saluran

\section{Pemodelan Aliran Tidak Tetap dengan HEC-RAS}

Penelusuran banjir adalah salah satu contoh pemodelan hidrolik dengan prinsip unsteady flow. Untuk aliran tak permanen, HEC-RAS memakai persamaan kekekalan massa (continuity, conservation of mass) dan persamaan momentum. Kedua persamaan dituliskan dalam bentuk persamaan diferensial parsial, yang kemudian diselesaikan dengan metode finite difference approximation berskema implisit (Istiarto, 2014). Persamaan kekekalan massa ini sejalan dengan prinsip Saint Vennant yang juga sebagai dasar dari Metode Kinematik.

\section{Pembuatan Peta Potensi Wilayah Tergenang dengan Sistem Informasi Geografis}

Pemetaan potensi wilayah tergenang dengan memanfaatkan program ArcMap terdiri atas 3 (tiga) langkah utama, yakni pre-processing, processing, dan post-processing. Pada tahapan pertama (pre-processing), dengan data masukan berupa DEM dan garis sungai yang diteliti, akan dihasilkan property fisik sungai seperti garis tengah aliran sungai (stream centerlines), arah aliran sungai (flow path centerline), tepian sungai (banks), hingga pototngan melintang (cross-section). 
Kedua, setelah proses pre-processing selesai, kemudian pada jendela baru HEC-RAS dibuat project baru. Pada bagian river geometry, dimasukkan data berupa olahan dari pre-processing sebelumnya. Kemudian, aliran dimodelkan unsteady flow. Seluruh data yang dihasilkan dari analisis ini kemudian diekspor ke dalam format GIS. Proses terakhir (postprocessing) dilakukan dengan menggunakan ArcMap dibantu ekstensi HEC-GeoRAS. Data yang menjadi masukan adalah hasil pengolahan pada pogram HEC-RAS. Dipilih menu Inudation Mapping untuk memetakan genangan.

\section{METODE PENELITIAN}

Metode penelitian yang digunakan adalah deskriptif kuantitatif. Analisis penelusuran banjir menggunakan metode Kinematik dengan bantuan hidrograf satuan sintetik Soil Conservation Service (HSS SCS) di Kali Pepe Hilir. Penelitian dilakukan di Kelurahan Sangkrah, Kecamatan Pasar Kliwon, Kota Surakarta, dengan memanfaatkan beberapa data sekunder yang meliputi:

1. Peta digital dengan skala 1:25 000 Kota Surakarta produksi Badan Informasi Geospasial (dahulu Bakosurtanal), termasuk di dalamnya peta administrasi, peta sungai, dan peta kontur.

2. Peta Digital Elevation Method (DEM) produksi United States Geological Survey (USGS)

3. Data curah hujan dari 3 (dua) stasiun terdekat dari wilayah tinjauan; yakni Stasiun Pabelan di bawah Balai Besar Wilayah Sungai (BBWS) Bengawan Solo serta Baki dan Mojolaban di bawah Balai Pekerjaan Umum Sumber Daya Air dan Penataan Ruang (BPUSDATARU) Bengawan Solo dari tahun 1998 sampai 2017.

4. Data potongan melintang sungai (cross section) yang didapatkan dari BBWS Bengawan Solo.

Data di atas kemudian diolah dengan menggunakan bebrapa perangkat digital yang terdiri dari:

1. Microsoft Excel untuk perhitungan analisis data hujan dan debit banjir.

2. ArcMap versi 10.2 untuk mengolah peta digital serta properti terkait pemetaan banjir di Kelurahan Sangkrah, Kecamatan Pasar Kliwon, Surakarta.

3. HEC-RAS versi 5.0.3 untuk pemodelan hidrolika sungai.

\section{HASIL DAN PEMBAHASAN}

\section{Penelusuran Banjir dengan Metode Kinematik}

Penelusuran banjir dilakukan pada Kali Pepe Hilir yang mengalir dari Pintu Air Tirtonadi hingga Pintu Air Demangan. Untuk mempermudah dan menghasilkan hasil analisis yang lebih akurat, maka sungai Pepe Hilir dibagi ke dalam 10 pias dengan jarak masing-masing pias adalah 550 meter. Tabel 1 menampilkan rekapitulasi hasil penelusuran banjir untuk masing-masing debit maksimum inflow dan outflow akibat hujan kala ulang dan akibat hujan 3-harian.

Tabel 1 Rekapitulasi Penelusuran Banjir pada Keadaan Debit Maksimum

\begin{tabular}{|c|c|c|c|c|c|c|c|}
\hline \multirow{2}{*}{ Pias ke- } & \multirow{2}{*}{ Aliran } & \multicolumn{6}{|c|}{ Kejadian Debit Maksimum (dalam m³/detik, jam ke-3) } \\
\hline & & $\mathrm{Q}_{5}$ & $\mathrm{Q}_{10}$ & $\mathrm{Q}_{25}$ & $\mathrm{Q}_{50}$ & $\mathrm{Q}_{100}$ & $Q_{3 \text { Harian }}$ \\
\hline \multirow{2}{*}{1} & Inflow & 37,29 & 41,48 & 44,47 & 49,35 & 52,20 & 101,73 \\
\hline & Outflow & 35,87 & 39,89 & 42,77 & 47,45 & 50,19 & 97,74 \\
\hline \multirow{2}{*}{2} & Inflow & 35,87 & 39,89 & 42,77 & 47,45 & 50,19 & 97,74 \\
\hline & Outflow & 33,75 & 37,53 & 37,53 & 44,62 & 47,19 & 91,80 \\
\hline \multirow{2}{*}{3} & Inflow & 33,75 & 37,53 & 37,53 & 44,62 & 47,19 & 91,80 \\
\hline & Outflow & 31,82 & 35,38 & 37,92 & 42,06 & 44,48 & 86,50 \\
\hline \multirow{2}{*}{4} & Inflow & 31,82 & 35,38 & 37,92 & 42,06 & 44,48 & 86,50 \\
\hline & Outflow & 30,70 & 34,13 & 36,58 & 40,57 & 42,90 & 83,37 \\
\hline \multirow{2}{*}{5} & Inflow & 30,70 & 34,13 & 36,58 & 42,90 & 42,90 & 83,37 \\
\hline & Outflow & 29,26 & 32,52 & 34,84 & 40,85 & 40,85 & 79,33 \\
\hline \multirow{2}{*}{6} & Inflow & 29,26 & 32,52 & 34,84 & 40,85 & 40,85 & 79,33 \\
\hline & Outflow & 27,60 & 30,67 & 32,86 & 38,51 & 38,51 & 74,69 \\
\hline \multirow{2}{*}{7} & Inflow & 29,26 & 30,67 & 32,86 & 38,51 & 38,51 & 74,69 \\
\hline & Outflow & 27,54 & 28,86 & 30,92 & 36,22 & 36,22 & 70,17 \\
\hline \multirow{2}{*}{8} & Inflow & 27,54 & 28,86 & 30,92 & 36,22 & 36,22 & 70,17 \\
\hline & Outflow & 25,92 & 27,16 & 29,09 & 34,07 & 34,07 & 65,92 \\
\hline \multirow{2}{*}{9} & Inflow & 25,92 & 27,16 & 29,09 & 34,07 & 34,07 & 65,92 \\
\hline & Outflow & 24,09 & 25,24 & 27,03 & 31,64 & 31,64 & 61,11 \\
\hline 10 & Inflow & 24,09 & 25,24 & 27,03 & 31,64 & 31,64 & 61,11 \\
\hline
\end{tabular}


Sesuai dengan pengembangan rumus Saint Vennant, debit masukan dari pias pertama adalah hasil perhitungan debit banjir rencana dengan menggunakan Hidrograf Satuan Sintetis (HSS) SCS. Kemudian, dengan menggunakan Persamaan 18 dan 19 didapatkan debit oufflow setiap pias dengan kala ulang 5, 10, 25, 50, dan 100 Tahun serta kejadian hujan 3-harian. Debit masukan (inflow) pada pias ke-2 senilai debit keluaran dari pias sebelumnya. Prinsip ini kemudian diterapkan untuk masing-masing pias hingga pias terakhir.

\section{Tinggi Muka Air}

Tinggi muka air dari masing-masing debit oufflow maksimum dicari dengan menggunakan iterasi dari Persamaan 20. Hasil dari perhitungan tinggi muka air tertera pada Tabel 2 hingga Tabel 7.

Tabel 2 Tinggi Muka Air Akibat $Q_{5}$

\begin{tabular}{cccc}
\hline Pias ke- & $\begin{array}{c}\text { Q hitung maksimum } \\
\left(\mathrm{m}^{3} / \mathrm{det}\right)\end{array}$ & $\begin{array}{c}\text { h maksimum } \\
(\mathrm{m})\end{array}$ & $\begin{array}{c}\text { Q model maksimum } \\
\left(\mathrm{m}^{3} / \mathrm{det}\right)\end{array}$ \\
\hline $\mathbf{1}$ & 36,223 & 1,442 & 35,5632 \\
\hline $\mathbf{2}$ & 34,599 & 1,702 & 33,4630 \\
\hline $\mathbf{3}$ & 33,094 & 1,195 & 31,5493 \\
\hline $\mathbf{4}$ & 32,212 & 0,784 & 30,4420 \\
\hline $\mathbf{5}$ & 31,054 & 1,078 & 29,0107 \\
\hline $\mathbf{6}$ & 29,702 & 1,025 & 21,2739 \\
\hline $\mathbf{7}$ & 29,650 & 0,957 & 24,9706 \\
\hline $\mathbf{9}$ & 28,305 & 0,798 & 21,3563 \\
\hline $\mathbf{1 0}$ & 26,752 & 0,905 & 21,0026 \\
\hline
\end{tabular}

Pada kejadian debit kala ulang 5 Tahun, tinggi air maksimum sebesar 1,702 $\mathrm{m}$ terjadi pada pias ke-2 dengan debit hasil penelusuran banjir pada pias tersebut sebesar $34,599 \mathrm{~m}^{3} /$ detik.

Tabel 3 Tinggi Muka Air Akibat $\mathrm{Q}_{10}$

\begin{tabular}{cccc}
\hline Pias ke- & $\begin{array}{c}\text { Q hitung maksimum } \\
\left(\mathrm{m}^{3} / \text { det }\right)\end{array}$ & $\begin{array}{c}\text { h maksimum } \\
(\mathrm{m})\end{array}$ & $\begin{array}{c}\text { Q model maksimum } \\
\left(\mathrm{m}^{3} / \mathrm{det}\right)\end{array}$ \\
\hline $\mathbf{1}$ & 40,2965 & 1,572 & 40,2969 \\
\hline $\mathbf{2}$ & 38,496 & 1,876 & 38,4960 \\
\hline $\mathbf{3}$ & 36,831 & 1,323 & 36,8310 \\
\hline $\mathbf{4}$ & 35,852 & 0,872 & 35,8520 \\
\hline $\mathbf{5}$ & 34,567 & 1,211 & 34,5674 \\
\hline $\mathbf{6}$ & 33,067 & 1,373 & 33,0671 \\
\hline $\mathbf{7}$ & 31,574 & 1,113 & 31,5740 \\
\hline $\mathbf{8}$ & 30,143 & 0,994 & 30,1430 \\
\hline $\mathbf{9}$ & 28,491 & 1,100 & 28,4910 \\
\hline $\mathbf{1 0}$ & 27,761 & 0,841 & 27,7610 \\
\hline
\end{tabular}

Pada kejadian debit kala ulang 10 Tahun, tinggi air maksimum sebesar 1,876 m terjadi pada pias ke-2 dengan debit hasil penelusuran banjir pada pias tersebut sebesar 38,496 m³/detik.

Tabel 4 Tinggi Muka Air Akibat $\mathrm{Q}_{25}$

\begin{tabular}{cccc}
\hline Pias ke- & $\begin{array}{c}\text { Q hitung maksimum } \\
\left(\mathrm{m}^{3} / \mathrm{det}\right)\end{array}$ & $\begin{array}{c}\text { h maksimum } \\
(\mathrm{m})\end{array}$ & $\begin{array}{c}\text { Q model maksimum } \\
\left(\mathrm{m}^{3} / \mathrm{det}\right)\end{array}$ \\
\hline $\mathbf{1}$ & 43,2049 & 1,651 & 43,2049 \\
\hline $\mathbf{2}$ & 41,280 & 1,970 & 41,2800 \\
\hline $\mathbf{3}$ & 39,502 & 1,386 & 39,5021 \\
\hline $\mathbf{4}$ & 38,455 & 0,912 & 38,4550 \\
\hline $\mathbf{5}$ & 37,080 & 1,269 & 37,0803 \\
\hline $\mathbf{6}$ & 35,474 & 1,439 & 35,4741 \\
\hline $\mathbf{7}$ & 33,877 & 1,275 & 38,8776 \\
\hline $\mathbf{8}$ & 32,345 & 1,041 & 32,3450 \\
\hline $\mathbf{9}$ & 30,576 & 1,151 & 30,5760 \\
\hline
\end{tabular}


Lanjutan Tabel 4

\begin{tabular}{|c|c|c|c|}
\hline 10 & 29,794 & 0,880 & 29,7940 \\
\hline \multicolumn{4}{|c|}{$\begin{array}{l}\text { Pada kejadian debit kala ulang } 25 \text { Tahun, tinggi air maksimum sebesar 1,970 m terjadi pada pias ke-2 dengan } \\
\text { debit hasil penelusuran banjir pada pias tersebut sebesar 41,280 m³ detik. }\end{array}$} \\
\hline \multicolumn{4}{|c|}{ Tabel 5 Tinggi Muka Air Akibat $Q_{50}$} \\
\hline Pis 1 to & Q hitung maksimum & h maksimum & Q model maksimum \\
\hline Pras ke- & $\left(\mathrm{m}^{3} / \mathrm{det}\right)$ & $(\mathrm{m})$ & $\left(\mathrm{m}^{3} / \mathrm{det}\right)$ \\
\hline 1 & 47,8225 & 1,772 & 47,8225 \\
\hline 2 & 45,698 & 2,117 & 45,6980 \\
\hline 3 & 43,740 & 1,484 & 43,7401 \\
\hline 4 & 42,584 & 0,975 & 42,5849 \\
\hline 5 & 41,066 & 1,359 & 41,0662 \\
\hline 6 & 39,292 & 1,542 & 39,2921 \\
\hline 7 & 37,527 & 1,246 & 37,5279 \\
\hline 8 & 35,834 & 1,112 & 35,8340 \\
\hline 9 & 33,878 & 1,230 & 33,8789 \\
\hline 10 & 33,014 & 0,939 & 33,0140 \\
\hline
\end{tabular}

Pada kejadian debit kala ulang 50 Tahun, tinggi air maksimum sebesar 2,117 m terjadi pada pias ke-2 dengan debit hasil penelusuran banjir pada pias tersebut sebesar 45,698 m³/detik.

Tabel 6 Tinggi Muka Air Akibat Q 100

\begin{tabular}{cccc}
\hline Pias ke- & $\begin{array}{c}\text { Q hitung maksimum } \\
\left(\mathrm{m}^{3} / \mathrm{det}\right)\end{array}$ & $\begin{array}{c}\text { h maksimum } \\
(\mathrm{m})\end{array}$ & $\begin{array}{c}\text { Q model maksimum } \\
\left(\mathrm{m}^{3} / \mathrm{det}\right)\end{array}$ \\
\hline $\mathbf{1}$ & 50,7209 & 1,848 & 50,7209 \\
\hline $\mathbf{2}$ & 48,473 & 2,207 & 48,4738 \\
\hline $\mathbf{3}$ & 46,403 & 1,544 & 46,4031 \\
\hline $\mathbf{4}$ & 45,179 & 1,014 & 45,1797 \\
\hline $\mathbf{5}$ & 43,572 & 1,414 & 43,5721 \\
\hline $\mathbf{6}$ & 41,694 & 1,605 & 41,6940 \\
\hline $\mathbf{7}$ & 39,825 & 1,296 & 39,8257 \\
\hline $\mathbf{8}$ & 38,032 & 1,155 & 38,0320 \\
\hline $\mathbf{9}$ & 35,960 & 1,279 & 35,9607 \\
\hline $\mathbf{1 0}$ & 35,044 & 0,976 & 35,0440 \\
\hline
\end{tabular}

Pada kejadian debit kala ulang 100 Tahun, tinggi air maksimum sebesar 2,207 m terjadi pada pias ke-2 dengan debit hasil penelusuran banjir pada pias tersebut sebesar $48,473 \mathrm{~m}^{3} /$ detik.

Tabel 7 Tinggi Muka Air Akibat Q3-harian

\begin{tabular}{cccc}
\hline Pias ke- & $\begin{array}{c}\text { Q hitung maksimum } \\
\left(\mathrm{m}^{3} / \mathrm{det}\right)\end{array}$ & $\begin{array}{c}\text { h maksimum } \\
(\mathrm{m})\end{array}$ & $\begin{array}{c}\text { Q model maksimum } \\
\left(\mathrm{m}^{3} / \mathrm{det}\right)\end{array}$ \\
\hline $\mathbf{1}$ & 98,927 & 3,005 & 98,9270 \\
\hline $\mathbf{2}$ & 94,666 & 3,601 & 94,6662 \\
\hline $\mathbf{3}$ & 90,775 & 2,448 & 90,7750 \\
\hline $\mathbf{4}$ & 89,445 & 1,599 & 89,4452 \\
\hline $\mathbf{5}$ & 87,889 & 2,294 & 87,8890 \\
\hline $\mathbf{6}$ & 86,031 & 2,657 & 86,0310 \\
\hline $\mathbf{8}$ & 84,138 & 2,138 & 84,1382 \\
\hline $\mathbf{9}$ & 82,281 & 1,922 & 82,2810 \\
\hline $\mathbf{1 0}$ & 80,071 & 2,173 & 80,0713 \\
\hline
\end{tabular}

Pada kejadian debit akibat hujan 3-harian, tinggi air maksimum sebesar 3,601 m terjadi pada pias ke-2 dengan debit hasil penelusuran banjir pada pias tersebut sebesar 94,666 m³/detik. 


\section{Pemetaan Wilayah Potensi Tergenang}

Pemetaan wilayah yang berpotensi tergenang dilakukan dengan menggunakan program ArcMap 10.2.1, yang hasilnya dapat dilihat pada Gambar 1 hingga Gambar 6.

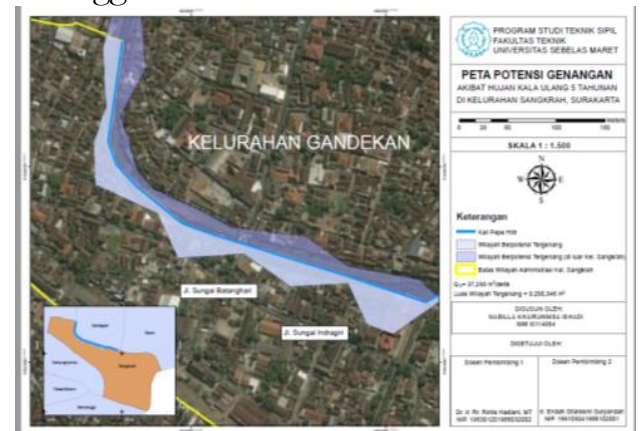

Gambar 1 Peta Potensi Genangan akibat Hujan Kala Ulang 5 Tahun

Gambar 1 di atas memperlihatkan pemetaan potensi genangan akibat banjir yang terjadi pada kala ulang 5 Tahun. Dapat dilihat pada peta bahwa banjir $Q_{5}$ berpotensi menggenangi seluas $9.290,346 \mathrm{~m}^{2}$ di wilayah Kelurahan Sangkrah, Surakarta.
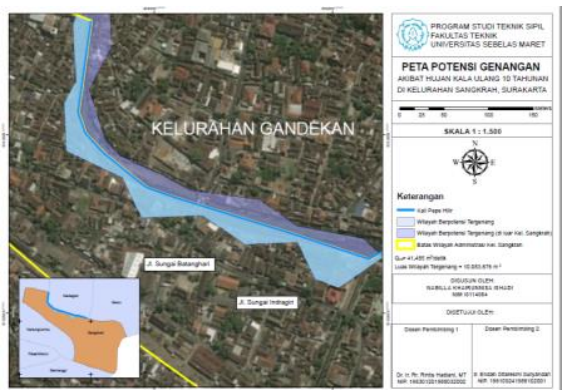

Gambar 2 Peta Potensi Genangan akibat Hujan Kala Ulang 10 Tahun

Gambar 2 di atas memperlihatkan pemetaan potensi genangan akibat banjir yang terjadi pada kala ulang 10 Tahun. Dapat dilihat pada peta bahwa banjir Q10 berpotensi menggenangi seluas $10.083,676 \mathrm{~m}^{2}$ di wilayah Kelurahan Sangkrah, Surakarta.
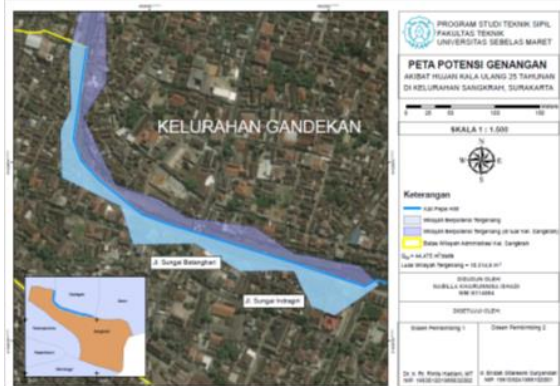

Gambar 3 Peta Potensi Genangan akibat Hujan Kala Ulang 25 Tahun

Gambar 3 di atas memperlihatkan pemetaan potensi genangan akibat banjir yang terjadi pada kala ulang 25 Tahun. Dapat dilihat pada peta bahwa banjir $\mathrm{Q}_{25}$ berpotensi menggenangi seluas $10.314,6 \mathrm{~m}^{2}$ di wilayah Kelurahan Sangkrah, Surakarta. 


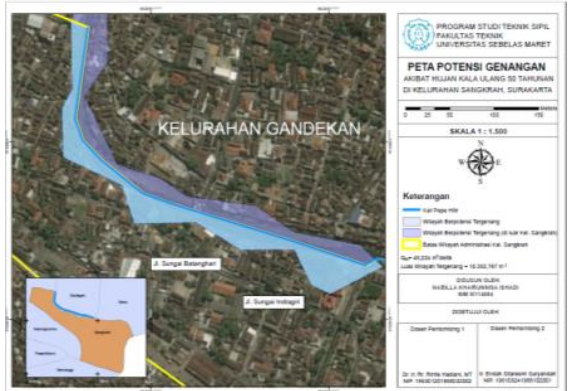

Gambar 4 Peta Potensi Genangan akibat Hujan Kala Ulang 50 Tahun

Gambar 4 di atas memperlihatkan pemetaan potensi genangan akibat banjir yang terjadi pada kala ulang 50 Tahun. Dapat dilihat pada peta bahwa banjir $Q_{50}$ berpotensi menggenangi seluas $10.352,767 \mathrm{~m}^{2}$ di wilayah Kelurahan Sangkrah, Surakarta.

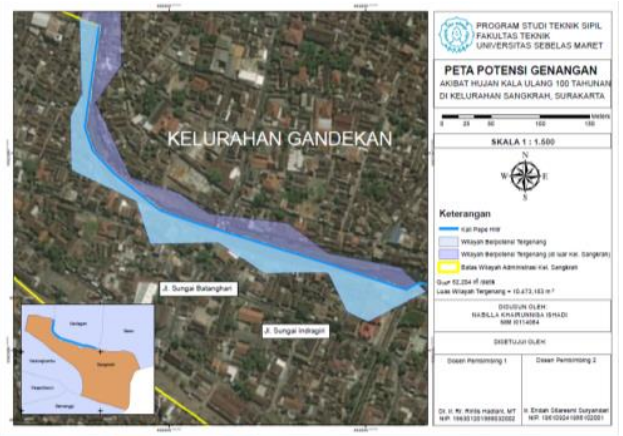

Gambar 5 Peta Potensi Genangan akibat Hujan Kala Ulang 100 Tahun

Gambar 5 di atas memperlihatkan pemetaan potensi genangan akibat banjir yang terjadi pada kala ulang 100 Tahun. Dapat dilihat pada peta bahwa banjir Q50 berpotensi menggenangi seluas $10.473,783 \mathrm{~m}^{2}$ di wilayah Kelurahan Sangkrah, Surakarta.

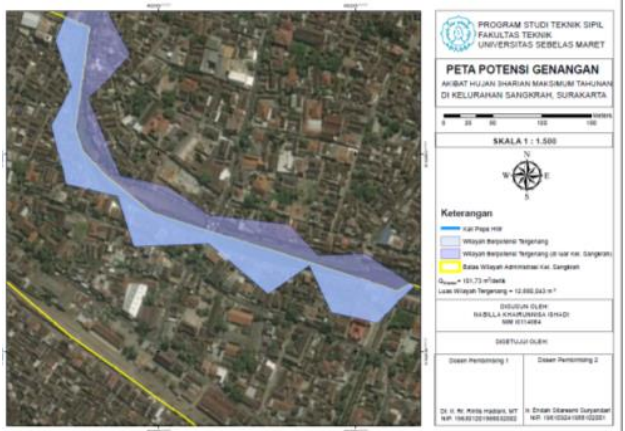

Gambar 6 Peta Potensi Genangan akibat Hujan 3-Harian Maksimum Tahunan

Gambar 6 di atas memperlihatkan pemetaan potensi genangan akibat banjir yang terjadi akibat hujan 3-harian. Dapat dilihat pada peta bahwa banjir $\mathrm{Q}_{3-H a r i a n}$ berpotensi menggenangi seluas 12.880,043 $\mathrm{m}^{2}$ di wilayah Kelurahan Sangkrah, Surakarta.

\section{SIMPULAN}

Debit banjir rencana periode ulang 5 Tahun $\left(\mathrm{Q}_{5}\right)$ adalah $37,295 \mathrm{~m}^{3} /$ detik, berpotensi menghasilkan tinggi muka air maksimum 1,702 $\mathrm{m}$ dan luasan tergenang $9.290,346 \mathrm{~m}^{2}$. Debit periode ulang 10 Tahun $\left(\mathrm{Q}_{10}\right)$ adalah 41,4855 $\mathrm{m}^{3} /$ detik berpotensi menghasilkan tinggi muka air maksimum 1,876 $\mathrm{m}$ dan luasan tergenang $10.083,676 \mathrm{~m}^{2}$. Debit periode ulang 25 Tahun $\left(\mathrm{Q}_{25}\right)$ adalah $44,475 \mathrm{~m}^{3} /$ detik, berpotensi menghasilkan tinggi muka air maksimum $1,970 \mathrm{~m}$ dan luasan tergenang 10.314,6 $\mathrm{m}^{2}$. Debit periode ulang 50 Tahun $\left(\mathrm{Q}_{50}\right)$ adalah, 49,224 m³/detik, berpotensi menghasilkan tinggi muka air maksimum 2,117 $\mathrm{m}$ dan luasan tergenang $10.352,767 \mathrm{~m}^{2}$. Debit periode ulang 100 Tahun $\left(\mathrm{Q}_{100}\right)$ adalah 52,204 m³/detik, berpotensi menghasilkan tinggi muka air maksimum 2,207 m dan luasan tergenang 10.473,183 $\mathrm{m}^{2}$. Debit banjir rencana maksimum akibat hujan 3-harian maksimum tahunan 
terjadi pada tahun 2007 yakni sebesar 101,73 m³/detik, berpotensi menghasilkan tinggi muka air maksimum $3,601 \mathrm{~m}$ dan luasan tergenang $12.880,043 \mathrm{~m}^{2}$.

\section{REKOMENDASI}

1. Ketersediaan data dengan format-format tertentu akan mempercepat hasil dari pengerjaan analisis, baik hidrologi maupun pemetaan, khususnya informasi mengenai data spasial di wilayah Indonesia.

2. Diperlukan adanya kajian lanjut mengenai banjir akibat sistem drainase untuk memperkuat hasil mengenai wilayah mana saja yang berpotensi tergenang.

\section{UCAPAN TERIMA KASIH}

Ucapan terima kasih pertama ditujukan kepada Allah SWT atas limpahan rahmat dan nikmatnya. Selanjutnya kepada Dr. Ir. Rr. Rintis Hadiani, M.T. dan Ir. Endah Sitaresmi Suryandari selaku dosen pembimbing yang telah memberi arahan dan masukan dalam penelitian ini.

\section{REFERENSI}

Andromeda, Virdya Nurlaily. 2013. Penelusuran Banjir di Sungai Temon Sub DAS Bengawan Solo Hulu III dengan Metode Muskingum-Cunge. Universitas Sebelas Maret. Surakarta

Chow, V.T., Maidment, D.R., and Mays, L.W. 1988. Applied Hydrology. McGraw-Hill. Singapore.

Dewandaru, Gemma Galgani Tunjung dan Umboro Lasmito. 2014. Studi Penanggulangan Banjir Kali Lamong Terbadap Genangan di Kabupaten Gresik. Jurnal Teknik POMITS. Volume 3, No. 2, (2014) ISSN:2337-3539

Flood Hydrology Manual. United States Bureau of Reclamation. 1989.

Hamdani, Hendi. dkk. 2014. Analisa Daerah Rawan Banjir Menggunakan Aplikasi Sistem Informasi Geografis (Studi Kasus Pulau Bangka). Jurnal Konstruksi. ISSN: 2302-7312 Vol. 12 No. 1.

Idfi, Gilang. 2017. Perbandingan Model Aliran Banjir Unsteady Flow dan Steady Flow pada Sungai Ngotok Ring Kanal. Jurnal Bangunan. Vol. 22, No.2, Oktober 2017: 31-40.

Jadmiko, Sigit., Rintis Hadiani, dan Agus Prijadi Saido. 2013. Banjir Tabunan Sub Daerah Aliran Sungai Bengawan Solo Hulu 3 dengan Sistem Informasi Geografis. Fakultas Teknik. Universitas Sebelas Maret. Surakarta.

Kurniawan, dkk. 2017. Mengisi Data Hujan yang Hilang dengan Metode Autoregressive dan Metode Reciprocal dengan Pengujian Debit Kala Ulang (Studi Kasus di D AS Bakalan). E-Jurnal Matriks Teknik Sipil, 13, 15-23.

Miller, Jeffrey E. 1984. Basic Concepts of Kinematic-Wave Models. U.S. Geological Survey Professional Paper 1302.

Montarcih, Lily. 2010. Penelusuran Banjir lewat Sungai : Studi kasus Sungai Dodokan. CV Citra Malang. Malang.

Naulita, Maria Anisa., Sobriyah, dan Siti Qomariyah. 2015. Metode Penelusuran Banjir pada Sungai Dengkeng dengan Metode Gabungan O'Donnel dan Muskingum-Cunge dan Metode Muskingum Extended. Fakultas Teknik. Universitas Sebelas Maret. Surakarta.

O’Donnell, T. 1985. A Direct Three-Parameter Muskingum Procedure Incorporating Lateral Inflow. Hydrological Sciences Journal, 30:4, 479-496. DOI : 10.1080/02626668509491013

Part 630: Hydrology National Engineering Handbook. 2010. United States Department of Agriculture.

Ponce, Victor Miguel. 1989. Engineering Hydrology : Principles and Practices. Prentice Hall Inc. New Jersey, United States of America.

Schwab, G.O., Fangmeir, D.D., Elliot, W.J., and Frevert, R.K. 1992. Soil and Water Conservation Engineering. Four Edition, John Wiley \& Sons. Inc, New York. Susanto, R.H. dan Purnomo, R.H (penterjemah). 1997.

Teknik Konservasi Tanah dan Air. CFWMS Sriwijaya University. Palembang.

Standar Nasional Indonesia. 2016. Tata Cara Perbitungan Debit Rencana. 2415:2016.

Sobriyah. 2012. Model Hidrologi. Sebelas Maret University Press. Surakarta.

Sobriyah dan Sudjarwadi. 2000. Penggabungan Metode O'Donnell dan Muskingum-Cunge untuk Penelusuran Banjir pada Jaringan Sungai. Media Teknik No. 4 Tahun XXII Edisi November 2000. ISSN 0216-3012.

Soewarno. 1995. Hidrologi: Aplikasi Metode Statistik untuk. Analisa Data Jilid 1. Penerbit Nova. Bandung.

Suripin. 2004. Sistem Drainase Perkotaan yang Berkelanjutan. Andi Offset. Yogyakarta. 